\title{
NEUROPATHIC PAIN IN PATIENT WITH POST OPERATIVE SCHWANNOMA: A CASE REPORT PRIMARY INTRADURAL EXTRAMEDULLAR SPINAL CORD TUMOUR
}

\author{
Widodo Mardi Santoso ${ }^{1}$, Siti Nurlaela ${ }^{1}$, Eko Arisetijono Marhaendraputro ${ }^{1}$, Dessika Rahmawati ${ }^{1}$ \\ Correspondence: sitinurlaela.dr@gmail.com \\ ${ }^{1}$ Department of Neurology Faculty of Medicine Brawijaya University, Malang, Indonesia.
}

Article History:

Received: February 18, 2017

Accepted: October 18, 2017

Published: July 1, 2019

\section{Cite this as:}

Santoso WM, Nurlaela $S$,

Marhaendraputro EA,

Rahmawati D. Neuropathic pain

in patient with post operative

schwannoma: a case report

primary intradural extramedullar

spinal cord tumour. Malang

Neurology Journal; 2019.5:86-

89. DOI:

http://dx.doi.org/10.21776/ub.mnj

.2019.005.2.7

\section{ABSTRACT}

Majority of spinal cord tumour is a benign tumour with symptoms are due to spinal cord compression. One of the symptoms that are often difficult to treat is a sensory deficit. The authors report a case of primary intradural extramedullar spinal cord tumour in 57-year-old man. This tumour was presenting symptoms of chronic low back pain, gradual progressive inferior paraplegia, and sensory deficit on both legs. MRI thoracal showed intradural lesion at Th 4-5-6, with isointensity on T1-weighted images and hyperintensity-isohomogen on T2-weighted images. The tumour was completely resected, and histopathology examination revealed schwannoma types. Patient showed a clinical improvement in motoric function noticeable after surgery, but showed sensory deficits sequelae requiring therapy for neuropathic pain.

Keywords: Tumour Intradural Ekstramedular, schwanoma

\section{Introduction}

Diseases of the nervous system can also occur in the spinal cord, which will give different manifestations. This syndrome is very dependent on the special anatomy and physiology of the spinal cord, for example the location of the spinal cord; long, cylindrical form of the spinal cord, with a relatively small diameter, with a meningen sheath; the location of myelinated nerve fibers located in the periphery adjacent to the piamater; unique vascularization; and its relationship with the vertebral column. ${ }^{1,2}$

Woolsey and Young estimate that there are more than 30 diseases that can manifest in the spinal cord, including tumours of the spinal cord. In general, neoplasms and other space-occupying lesions in the spinal canal can be divided into two groups: (1) lesions that appear in the spinal (intramedullary) and (2) lesions that appear outside the spinal cord (extramedullary), these lesions then divided into lesions that arise from nerve roots or leptomeningen (intradural), or epidural and vertebral (extradural) tissue. ${ }^{1,2}$

Based on research by the Mayo Clinic, of 8784 cases of CNS tumours, $15 \%$ were spinal cord tumours. From other studies, data showed that $5 \%$ were intramedullary tumours, $40 \%$ were intradural-extramedullary tumours, and 55\% were extradural, where the majority of extradural tumours were metastases. ${ }^{1,2}$
Unlike brain tumours, the majority of spinal cord tumours are benign tumours with symptoms due to compression of the spinal cord. With one complication that is often difficult to treat is a sensory disorder due to compression of the spinal cord. ${ }^{2,3}$

This case report tried to explain the diagnosis and management of spinal cord tumours so that they could provide better outcomes.

\section{Case Report}

Male, 57 years old, came to the nerve clinic at Saiful Anwar General Hospital Malang with complaints of weakness on both legs gradually since 6 months ago. Initially, weakness in the left leg was felt, still able to walk with propagation, but since 2 months the weakness in the left leg was felt more severe, followed by weakness in his right leg.

Patient also felt numbness and tingling on both legs to chest. These symptom was felt oh his left foot since 6 months ago, followed by his right foot since 2 months ago.

Patients often felt back pain since 2 years ago. Pain was limited on the back, not spreading. Back pain appeared and increased after activity, it would decrease after break. Defecation and urination within normal limits. History of fever, weight loss, prolonged coughing, trauma, lumps in other parts were denied. 
Examination of internal status and vital signs was within normal limits. From a neurological status examination, power motor right leg lower was 3 (MMT scale), left lower leg was 2 (MMT scale), with normal hand motoric strength. There was increased tone (spastic) in both lower extremities increase physiological reflexes bilateral patellar and achilles reflexes, and bilateral babinski $+/+$ reflexes. From the sensory system, segmental parasthesia according to the Th6 dermatome and below were obtained.

Lumbosacral AP/Lateral/ Oblique X-ray examination results showed osteophytes at VL2-5, while contrast MRI thoracal showed intradural mass on the left side as high as Th4-5-6, isointens on T1W1 and hyperintense-isohomogen at $\mathrm{T} 2 \mathrm{~W} 1$ that push spinal cord, suggestive of meningioma or schwannoma (Figure 1)

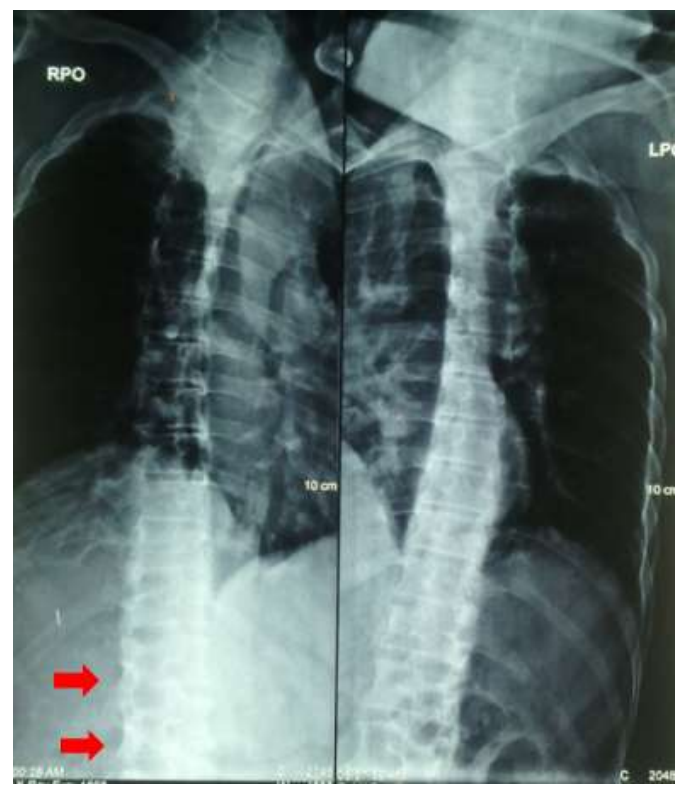

Figure 1. AP /lateral thoracolumbal x-ray showing osteophytes in the lumbar vertebral body $2-5$
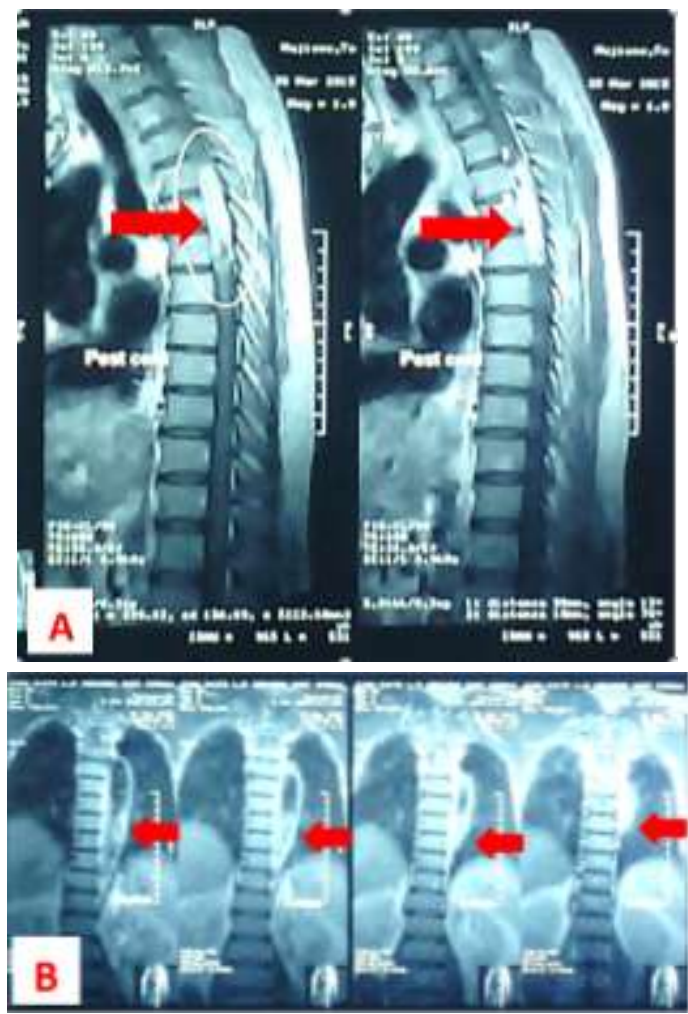

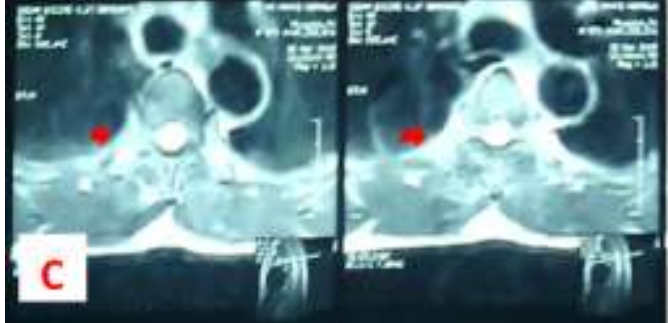

Figure 2. Sagittal ( A), coronal (B) and axial (C) cut thoracal MRI results showing intradural mass on the left side as high as Th4-56 , isointense on T1W1 and hyperintense-isohomogen at T2W1 and after contrast administration push spinal cord in the area.

Patient then performed a total excision of the tumour, with pathology results showing tissue consisting of spindleshaped proliferation of mesenchymal cells, partially arranged in a row and forming a picture of the verrocay body, suggesting schwannoma.

One week after surgery, motor strength began to increase and heal completely after 3 months postoperatively. However, patient still having segmental dysesthesia according to Th6, so patients still need to consume neuropathic pain medication (Gabapentin 2x100 mg).

\section{Discussion}

In this case the diagnosis was determined based on the clinical finding, both from history and physical examination, supported by several additional examinations including laboratory and imaging, the diagnosis was confirmed by histopathological examination.

In general, neoplasms and other space lesions in the spinal cord can be divided into two groups, namely (1) lesions that appear in the spinal cord (intramedullary) and (2) lesions that appear outside the spinal cord (extramedullary), these lesions are then divided again becomes lesions that arise from nerve roots or leptomeningen (intradural), or epidural tissue and vertebral (extradural) tissue. Thus, the clinical manifestations of the spinal cord tumour are highly dependent on the location of the tumour. The differences in clinical manifestations of spinal cord tumours can be seen in table $1 .{ }^{1.2}$

Table 1. Clinical manifestation of spinal cord tumour.

\begin{tabular}{|c|c|c|}
\hline & $\begin{array}{c}\text { Intramedullary } \\
\text { tumour }\end{array}$ & $\begin{array}{c}\text { Extramedullary } \\
\text { tumour }\end{array}$ \\
\hline Pain & $\begin{array}{l}\text { Atypical, diffuse } \\
\text { pain }\end{array}$ & $\begin{array}{l}\text { Radicular/regional } \\
\text { pain }\end{array}$ \\
\hline $\begin{array}{l}\text { Sensoric } \\
\text { manifest- } \\
\text { tation }\end{array}$ & $\begin{array}{l}\text { Sensoric } \\
\text { dissociation, } \\
\text { longitudinal } \\
\text { spreading of sensoric } \\
\text { manifestation }\end{array}$ & $\begin{array}{l}\text { Contralateral } \\
\text { anaesthesia and } \\
\text { thermanastesia }\end{array}$ \\
\hline $\begin{array}{l}\text { Lower } \\
\text { motor } \\
\text { neuron } \\
\text { sign }\end{array}$ & $\begin{array}{l}\text { Atrophy dan } \\
\text { fasciculation }\end{array}$ & Segmental \\
\hline $\begin{array}{l}\text { Upper } \\
\text { motor } \\
\text { neuron } \\
\text { sign }\end{array}$ & Less prominent & $\begin{array}{l}\text { More prominent, } \\
\text { early, paresis with } \\
\text { hyperreflexia }\end{array}$ \\
\hline Autonom & $\begin{array}{l}\text { Frequently affected, } \\
\text { early. Horner } \\
\text { syndrome can appear } \\
\text { if lesion is in lower } \\
\text { cervical }\end{array}$ & Less affected \\
\hline
\end{tabular}


It is difficult to distinguish extradural and intradural tumours from extramedulla only from history and physical examination. Extradural lesions can also be suspected if radicular pain is present in the early stages of the disease, vertebral examination is radiologically painful, deformed or abnormal, the presence of motoric disorders precedes sensory disorders, and the latter appears autonomic disorders. ${ }^{1,2}$

In this patient, weakness in both legs was felt gradually since 6 months ago. Initially, weakness was felt in the left leg, still able to walk with help, but since 2 months the weakness in the left leg was felt more severe, followed by weakness in his right leg. The patient also felt numbness and tingling on both legs to the chest. Numbness and tingling was first felt on the left foot since 6 months ago, followed by his right foot since 2 months ago.

Patient felt pain in the back since 2 years ago. Pain was felt limited to the back, not spreading. Back pain appeared and increased with activity, decreased with rest.

Next step was to determine the height of the lesion. In determining the level of the lesion, it should be noted about the location of back pain, radicular pain, the highest level of hypoalgesia, motoric abnormalities (especially atrophy paralysis) and autonomic abnormalities. ${ }^{1,2}$ In this patient, inferior paraparesis with segmental hypesthesia and parastesias corresponding to Th 6 dermatomes supported by the perspiration test result. Imaging examination (thoracic MRI with contrast) found an intradural mass on the left side as high as Vertebrae Th 4-5-6.

Differential diagnosis of intradural extramedullary tumours can be benign or malignant, primary or metastatic tumours, with the majority being primary benign tumours. From the MRI results, a picture of meningioma was obtained. However, from the histopathological examination results, the tissue consisted of proliferation of spindle-shaped mesencymal cells, partially arranged in a row and forming a picture of the verrocay body that supports the diagnosis of schwannoma.

The prognosis of spinal cord tumours is strongly influenced by age, the clinical condition of the patient, the etiology of the tumour itself, whether a tumour is benign or malignant, primary or metastatic, size and location of the tumour, suitability of diagnosis and accuracy of therapy, response to therapy, and tumour spreading to other organs. ${ }^{2.5}$ In this patient, the clinical condition of the patient was good with benign primary tumour type and tumour excision could be performed completely.

The outcome of surgery is strongly influenced by the patient's preoperative clinical condition, tumour location and tumour etiology. Severe long-term complications after surgical excision of intradural extramedullary tumours, especially nerve sheath tumours are very rare. These tumours can generally be treated with total excision with a high life expectancy. ${ }^{2,8,9}$

Normal tissue and nerves that are disturbed or damaged by tumours will need time to heal. Some symptoms can disappear over time. Rehabilitation and counseling will help patients and families adapt better and improve their quality of life.

Physical therapy can help regain motor strength, movement coordination and balance. Occupational therapy can teach patients to use new ways to complete tasks. Supportive therapy can help patients deal with pain and other symptoms. Based on research by Kose, et al. (2014), it was shown that rehabilitation as soon as patients are stable after spinal cord surgery (after 2-7 days) significantly increases sensory, motoric, and daily activity of patients. ${ }^{6}$ The literature review conducted by Raj, et al (2013) also shows that rehabilitation had a positive effect on patients with spinal cord tumours. ${ }^{7}$ Patients with benign tumours showed the most significant improvement. However, patients with metastases also showed improvements in aspects of function, mood, quality of life, and life expectancy after rehabilitation. Patients with American Spinal Asia Injury Impairment Scale A-C showed reduction in pain, opioid use and the incidence of depression. They were also more satisfied with life, and able to move independently. Handling the right bladder and rectum can prevent complications and discomfort from irritated skin in patients with spinal cord lesions.

In this patients, there was an improvement from the postoperative clinical aspect in the form of improvement in muscle strength, even though the sensory function was still impaired. Age of patient, good clinical condition of the patient etiology of benign tumours (schwannoma), complete resection of spinal cord tumour, and early rehabilitation improved outcomes in this patients. There was still sequelae in this patient, in the form of persistent postoperative dysesthesia, it was possible because of the ischemic effect due to compression of myelum by the spinal cord tumour so that necrosis has occurred in sensory nerve fibers. In addition, schwannoma often arises from the dorsal or sensory nerve roots so that resection possibly disconnect sensory roots.

Dysesthesia or abnormal sensation is defined as an unpleasant, abnormal sense of touch. It is typical in neuropathic pain, which is caused by nerve injury. There is a broad agreement among the guidelines on pharmacological treatment of neuropathic pain. Three drugs classes have received strong recommendations for first-line therapy in all guidelines: tricyclic antidepressants, particularly amitriptyline; the serotonin-norepinephrine reuptake inhibitors (SNRIs) such as duloxetine; and the calcium channel alpha-2-delta ligands gabapentin and pregabalin. In this case, we chose gabapentin as neuropathic pain treatment because of drug availability and cost consideration in Indonesia among other drugs. ${ }^{1,2,4}$

\section{Conclusion}

A 57-year-old man with intradural extramedullary tumour at vertebral 5-6 with schwannoma etiology was reported. The diagnosis was made clinically and was supported by imaging data. The etiological diagnosis was confirmed by histopathology examination. Patient undergone excision of the tumour and laminectomy with clinical improvement in muscle strength after surgery, but still had sensory disturbances, so that this patient still needed postoperative neuropathic pain drugs. Gabapentin was chosen as treatment for neuropathic pain due to drug availability and cost consideration. To improve outcomes, early rehabilitation was carried out. 


\section{Acknowledgement}

The authors would like to thank to Brawijaya University and Dr. Saiful Anwar General Hospital, Malang, East Java, Indonesia for facilitating this case report study.

\section{References}

1. Ropper AH, Brown RH. Adams and Victor's Principles of Neurology $10^{\text {th }}$ edition. New York: McGraw Hill. 2014

2. DeMonte F, Gilbert MR, et al. Tumours of The Brain and Spine. New York: Spinger Science Business Media. 2007

3. Baehr M, Frotscher M. Diagnosis Topis Neurologi Duus. Jakarta: EGC. 2010

4. Netter FH, Craig JA, et al. Atlas of Neuroanatomy and Neurophysiology. USA: Icon Custom Communications. 2012

5. National Institute of Neurological Disorders and Stroke. Brain and Spinal Cord Tumours. Bethesda: Department of Health and Human Services. 2009
6. Kose N, Muezzinoglu O, et al. Early rehabilitation improves neurofunctional outcome after surgery in children with spinal tumours. Neural Regen Res; 2014.15;9(2):129-134. DOI: 10.4103/16735374.125340

7. Raj VS, Lofton L. Rehabilitation and treatment of spinal cord tumours. J spinal Cord Med; 2013. 36(1): 4-11. DOI: $10.1179 / 2045772312$ Y.0000000015

8. Avramov $\mathrm{T}$, Kyuchukov $\mathrm{G}$, et al. Results of spinal tumours surgery. Journal of IMAB - Annual Proceeding (scientific Papers), book 1. 2009. Available from: https://www.journal-imab-bg.org/statii09/vo109_1_84-88str.pdf.

9. Rahmawati D, Marhaendraputro EA, Kurniawan SN, Wirathmawati A. Extracranial metastasis of glioblastoma: a rare case. Malang Neurology Journal; 2019.5:51-54. DOI: http://dx.doi.org/10.21776/ub.mnj .2019.005.01.10 